\title{
A New Method for Contrasting Energy Performance and Near-Zero Energy Building Requirements in Different Climates and Countries
}

\author{
Kaiser Ahmed ${ }^{1, *}$, Margaux Carlier ${ }^{2}$, Christian Feldmann ${ }^{3}$ and Jarek Kurnitski ${ }^{1,4}$ (D) \\ 1 Department of Civil Engineering, Aalto University, Rakentajanaukio 4 A, FI-02150 Espoo, Finland; \\ jarek.kurnitski@ttu.ee \\ 2 Faculty of Engineering and Architecture, Ghent University, 9000 Ghent, Belgium; margaux.carlier@UGent.be \\ 3 Association of Engineers in Heating, Ventilation and Air Conditioning AICVF, 75008 Paris, France; \\ ch.feld@yahoo.com \\ 4 Department of Civil Engineering and Architecture, Tallinn University of Technology, 12616 Tallinn, Estonia \\ * Correspondence: kaiser.ahmed@aalto.fi
}

Received: 11 April 2018; Accepted: 18 May 2018; Published: 23 May 2018

\begin{abstract}
In this study a robust method enabling one to compare the energy performance in different climates was developed. Derived normalization factors allow "to move" the building from one climate to another with corresponding changes in heating, cooling, and electric lighting energy. Degree days, solar-air temperature and economic insulation thickness were used to normalize space heating and cooling needs. Solar-air temperature based degree days resulted in 5\% accuracy in space heating and dry-bulb air temperature based cooling degree days were trustworthy in cooling need normalization. To overcome the limitation of the same thermal insulation in all climates, an economic insulation thickness was applied. Existing and nearly zero energy requirements were contrasted in four countries with a reference office building to analyze the impacts of climate and national regulation on primary energy use. By applying standard energy calculation input data and primary energy factors from European standards to buildings with national technical solutions, nearly zero energy building requirements comparison with European Commission benchmarks was possible to conduct. Generally, in Central and North Europe comparison, national input data caused much more difference than the climate.
\end{abstract}

Keywords: national regulation; energy performance; primary energy requirement; climate correction; economic insulation thickness; NZEB

\section{Introduction}

The comparison of heating and cooling need in buildings in different locations is difficult because of the variations in building parameters, occupancy, thermal comfort, and climate. Applying the same measures does not ensure the assignment of similar amounts of energy savings in different climatic regions. For instance, the effect of reflective coatings on the energy needs of residential buildings were estimated and the results showed a $40 \%$ cooling load reduction in Athens, $51 \%$ in Barcelona and 59\% in Nice [1]. Thus, climate shows a significant effect on the energy efficiency of buildings [2]. Many studies have reviewed energy use in buildings from different climatic regions [3,4]. Five major climatic variables, namely dry-bulb temperature, wet-bulb temperature, wind speed, global solar radiation, and clearness index were considered and it was described how those parameters were correlated with heating and cooling needs [5]. In a similar context, a study described in [6] concluded that the energy requirements of buildings were closely linked to the climatic variables, but mainly air temperature. This study also investigated the impact of air temperature variation on 
energy requirements by using the degree days method [6]. This method estimates the energy need proportionality related to the difference between base temperature and outdoor temperature. It is concluded in [7] that the use of a constant base temperature could lead to considerable errors, because it could not explicitly account for the dynamic behaviour of weather, solar radiation, internal heat gains, thermal mass, building type, and other building parameters. Similar conclusions were drawn by [8] while estimating the energy performance of Italian buildings. The degree days approach leads to significant errors during the cooling season, because cooling load is much more dependent on solar radiation and internal gains [8]. To overcome these problems, it is generally proposed to evaluate the energy performance of a building using dynamic energy simulation models $[9,10]$.

The energy performance of a building is expressed typically with specific energy use in $\mathrm{kWh} /\left(\mathrm{m}^{2} \cdot \mathrm{a}\right)$, also called Energy Efficiency Index (EEI) in [11]. A relative energy index $\left(\mathrm{EEI}_{\mathrm{B}}\right)$ was proposed in [12] that is defined as the ratio between energy use or $\mathrm{CO}_{2}$ emission of actual building and the reference building that can be used for a common framework of a certification scheme. Instead of the reference building value, it is also possible to use a national energy performance requirement. The Energy Performance of Buildings Directive (EPBD) requires the use of primary energy index in $\mathrm{kWh} /\left(\mathrm{m}^{2} \cdot \mathrm{a}\right)$ for all countries [13].

Energy calculations of heating and cooling needs are typically normalized for reference a year or climate (location) with heating and cooling degree days. This represents an outdoor temperature correction, which does not take into account the effects of solar gains. Solar-air temperature, applied in this study, allows improving the accuracy of normalization and the correction factors can be still calculated from climate files. In both cases, the base temperature is the only building specific data that needs to be known with reasonable accuracy or has to be simulated. Normalization will result in the same heating and cooling needs for two buildings at different locations, if one of these buildings were to be 'moved' to another climate. In such a case, it is assumed that in colder and warmer climates buildings have the same thermal insulation, which is usually not the case. Therefore, an economic insulation thickness concept may be applied in order to ensure that buildings are optimally insulated in both climates. Such analyses were conducted in [14-17].

The optimum insulation thickness was determined in [18], which also presented the optimal cost solution for buildings of four climate zones in Greece. Similarly, in the European Union (EU), cost optimality methodology was developed and set as an EU regulation [13]. With this cost optimality methodology, reference residential buildings in 36 representative locations across Europe were simulated in order to determine cost optimal solutions for each location with a 30 years net present value calculation period [19]. Such detailed simulations results in optimal insulation and other technical solutions in each climate, showing differences both in energy use and technical solutions. The limitation of the method is that it needs large amount of detailed energy simulations basically to just solve an optimization exercise. Moreover, a single measure cost effectiveness method was introduced in [20], which allows one to avoid optimization, but still requires detailed energy and cost calculations. Therefore, in this study, an economic insulation thickness, which can be simply calculated from degree days, is applied for a robust energy performance comparison of buildings in different climates.

The Energy Performance of Buildings Directive (EPBD) set an ambitious near-zero energy building (NZEB) energy performance target [21]. According to the NZEB definition in the directive, these buildings shall have a very high energy performance. High energy performance is defined for Member States (MS) who use their national methodology for energy calculations. This creates the need to compare the energy performance of buildings built according to the respective national requirements.

The role, limitations and differences of the energy regulation and certification schemes in Europe were analyzed in [22]. As national energy performance values depend on energy calculation input data and calculation rules, it is important to know how much variation these can cause. If the difference is significant, the comparison becomes more complicated. A building, which exactly complies with the requirements in one country, can be simulated with input data and calculation methodology of 
another country in order to see how close the technical solutions of this building are to the energy performance requirement of that another country. Input data and calculation methodology problems can be solved with a common methodology, which is available in the form of energy performance building (EPB) standards described in the overarching standard ISO 52000-1:2017 [23]. In the case of standardized input data and the same energy calculation methodology, this problem does not exist.

Few studies are available in the literature that compare the national regulations on energy efficiency. The energy performance of Italian and Spanish buildings that were located in various climate regions was compared in [24]. It was concluded that the Italian regulations, which were valid for the year 2006, were less strict compared to the Spanish regulations. In a similar context, a comparison of Finnish, Danish, Swedish and Norwegian requirements for a detached house, apartment building and office building was conducted based on simulation results [25]. The results showed that Danish requirement for office buildings was the most stringent one, followed by Sweden, Norway, Estonia, and Finland. A simplified method was also proposed based on conversion of delivered energy requirements which considered the degree day normalization [25]. For comparison of building energy performance level in 2013, the simplified method worked with little variations compared to the simulation results, however it was stressed that the degree day normalization might not work for highly energy performing buildings.

The European Commission (EC) Joint Research Centre has recently evaluated all existing national NZEB definitions [26]. National NZEB requirements were found to be quite different in terms of numeric values, building categories to which they apply, energy flows included and renewable energy accounting, as well as national input data used for the energy calculations. Since comparison and assessment of national NZEBs is challenging, the EC has published official recommendations, EU 2016/1318 [27], in order to ensure that it is possible to meet NZEB targets by 2020. The main recommendations reflect EC concerns about the low ambition of national NZEB targets as well as the time schedule challenge to deliver NZEB by the end of 2020. It is also stressed that national NZEB definitions should not be below the cost-optimal level of minimum requirements and proper indoor environmental parameters are to be assured to avoid deterioration of indoor air quality (IAQ), comfort, and health. EC set numeric benchmarks for NZEB primary energy use, which are discussed in Section 2.2.

NZEB buildings represent the aspect of energy performance requirement comparison for high performance buildings. Similarly, energy performance comparisons could be in the interest of investors or building owners for existing buildings at different locations. Real estate property owners often manage a large number of office and commercial buildings in different countries. They benchmark energy performance of buildings in their property stock (to decide energy performance improvement measures, renovations etc.), but benchmarking without climate normalization does not provide objective results. Another need of comparison is created by the energy performance minimum requirements which have recently changed due to NZEB, and because of different national methodologies it is not clear which countries have stringent requirements.

Such comparison needs were foreseen in the EPBD, which Article 11 proposes establishing a voluntary common European Union certification scheme for the energy performance of non-residential buildings. However, the development of this scheme has turned out to be more complex than expected and such a scheme is not yet available. This paper contributes to this topic by developing a new method enabling climate and national input data and methodology dependent comparison. In order to enable physically meaningful comparison of energy performance, the method should be able to address three major issues:

(1) To normalize space heating, cooling and lighting needs in different climates;

(2) To account national methodology and input data differences;

(3) To consider cost effectiveness constraints such as economic insulation thickness in different climates. 
The objective of this study was to develop a reliable and robust energy performance climate correction method, which enables energy performance comparisons with acminimum amount of building specific parameters. We show the limitations of degree day normalization and an improvement through solar-air temperature degree days, which provided reasonable accuracy but assume the same thermal insulation in both climates under comparison. To conduct comparisons between two climatic zones, Oceanic and Nordic, we applied an economic insulation thickness concept that allows us to adjust insulation according to the climate. A reference office building [28] was used to analyze the 2016 (present minimum requirements) and 2021 (NZEB) building regulations from Finland (Nordic) [29], Estonia (Nordic) [30,31], France (Oceanic) [32], and Belgium (Oceanic) [33,34]. A reference office building with economic insulation thickness and otherwise with the same technical solution was simulated with national input data. The technical solutions such as building envelope components insulation, solar system, heating, ventilation, and cooling (HVAC) system performance, etc. were selected so that the building complied with national PE requirements. Primary energy values simulated with national input data were then compared with national requirements in other countries, and if a gap existed, the technical solutions were changed to minimize the gap. The requirement of the country corresponding to the technical solutions with highest performance level express the strictest NZEB level. By applying standard energy calculation input data from European standards to buildings with national technical solutions, national NZEB requirements comparison with EC benchmarks was conducted. Developed method based on the economic insulation may be utilized in the development of voluntary European certification scheme for the energy performance.

The methodology is validated for heating dominated Central and North European climates for office buildings only. This study used the optimal insulation thickness depending on the climate but did not change anything for the cooling. The Mediterranean climate may need something similar to account in order to find out the differences in the cooling.

\section{Methods}

In this study two methods, a simple normalization factor and reference building energy simulation method, were developed and tested for energy performance comparison of office buildings in different climates. The main features of the methods are shown in Figure 1.

In the normalization factor method energy uses of heating, cooling and lighting in one country are multiplied with normalization factors derived in this study. Figure 1a shows an example of how the energy use of a French office building can be converted to Estonia with the aim to be comparable with similar Estonian buildings. The method can be applied for metered energy data, and basically no calculations or simulations are needed.

The reference building simulation method (Figure $1 b$ ) is a more sophisticated method where energy simulations are to be ran, but the method allows one to take into account that buildings are less insulated in warmer climates, which is not the case with the normalization factor method. In the simulation method, building envelope insulation is adjusted according to the climate, standard input data is applied and energy simulations will be run with test reference years of both locations under comparison.

This method is applied in this study for the comparison of national energy performance requirements. It should be noted that the method is limited to heating dominated climates as the building envelope insulation is the only climate dependent adjustment done. For cooling solutions no adjustments are done and therefore the method is not suitable for cooling-dominated hot climates for which further development would be needed. In the following the methods applied for heating and cooling energy normalization with degree days and to determine optimal insulation thickness in different climates are described. For the national energy performance requirements comparison, 2016 and 2021 requirements and European commission recommendations for NZEB performance levels are reported for selected countries. 


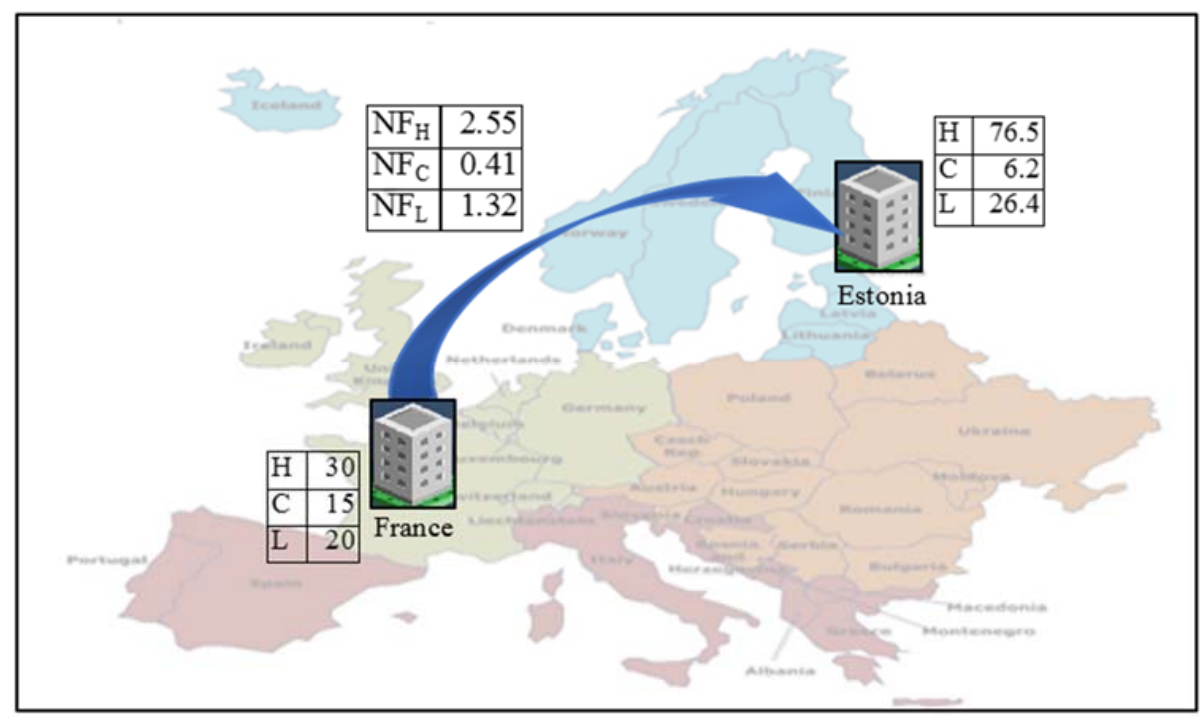

(a)

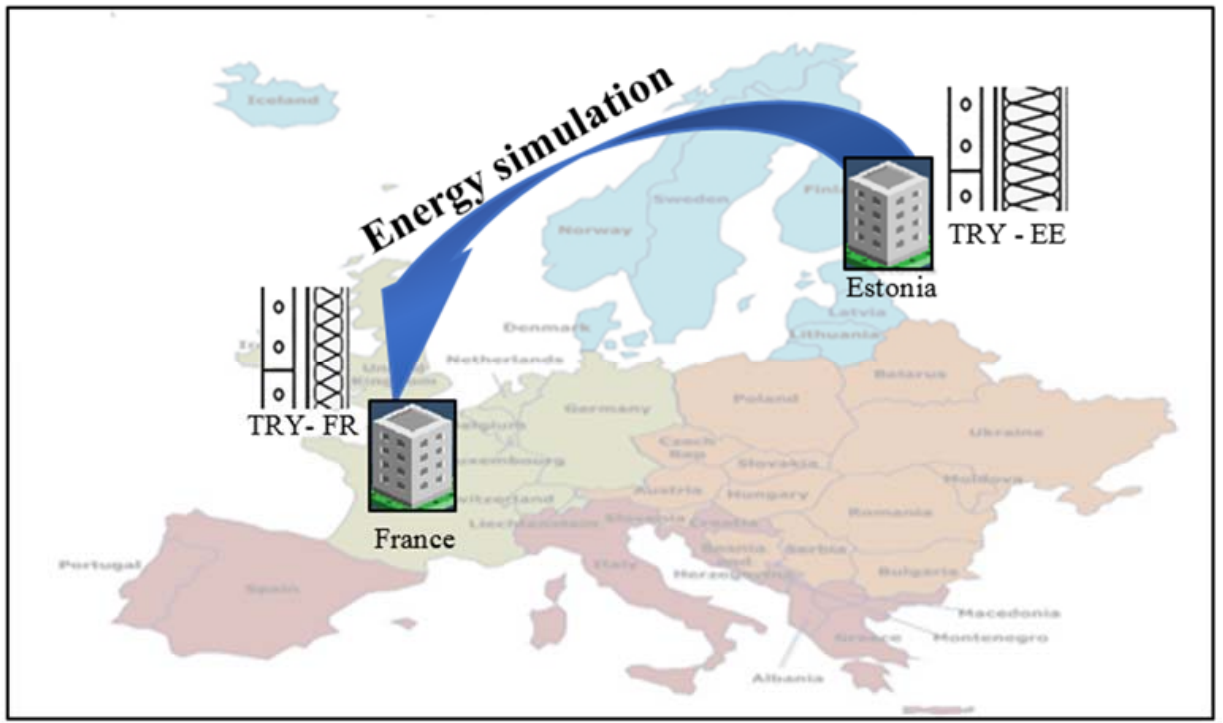

(b)

Figure 1. Schematic diagram of developed methods for energy performance comparison in different climates. (a) simple normalization factor (NF) method to convert heating (H), cooling (C) and lighting (L) energy use in $\mathrm{kWh} /\left(\mathrm{m}^{2} \cdot \mathrm{a}\right)$ from one country to another; and (b) reference building energy simulation method, which adjusts building envelope insulations and uses local test reference year (TRY).

\subsection{Climate Corrections}

For climate correction, normalization with dry-bulb temperature and solar-air temperature degree days were applied. The latter allows one to account for the effect of solar radiation on opaque building surfaces such as roofs and walls by increasing the outdoor temperature. Solar-air temperature was calculated with following equations based on the heat flux from exterior surface subjected to solar radiation [35]:

$$
\begin{gathered}
Q_{\text {Surface }}=Q_{\text {conv }+ \text { rad }}+Q_{\text {Solar }}-Q_{\text {radiation correction }} \\
Q_{\text {Surface }}=h_{o} A_{S}\left(T_{o}-T_{S}\right)+\alpha_{S} A_{s} q_{\text {solar }}-\varepsilon \sigma A_{s}\left(T_{o}{ }^{4}-T_{\text {surr }}{ }^{4}\right) \\
Q_{\text {Surface }}=h_{o} A_{S}\left(T_{\text {sol-air }}-T_{S}\right)
\end{gathered}
$$




$$
T_{\text {sol-air }}=T_{0}+\frac{\alpha_{s} q_{\text {solar }}}{h_{0}}-\frac{\varepsilon \sigma\left(T_{o}^{4}-T_{\text {surr }}^{4}\right)}{h_{0}}
$$

where, $Q_{\text {Surface, }}$, heat flow into the exterior surface $(\mathrm{W}), Q_{\text {conv+rad }}$, convective and radiative heat flow into the exterior surface $(\mathrm{W}), Q_{\text {Solar }}$, solar heat flow $(\mathrm{W}), Q_{\text {radiation correction, }}$, the correction for the radiation heat transfer when $T_{\text {surr }} \neq T_{o}(\mathrm{~W}), h_{o}$, heat transfer coefficient for radiation (long wave) and convection $\left(\frac{\mathrm{W}}{\mathrm{m}^{2} \cdot \mathrm{K}}\right), T_{0}$, ambient temperature $\left({ }^{\circ} \mathrm{C}\right), A_{s}$, surface area $\left(\mathrm{m}^{2}\right), T_{s}$, surface temperature $\left({ }^{\circ} \mathrm{C}\right), \alpha_{s}$, solar radiation absorptivity $(-), q_{\text {solar }}$, solar irradiance $\left(\frac{\mathrm{W}}{\mathrm{m}^{2}}\right), \varepsilon$, surface emissivity $(-), \sigma$, Stefan-Boltzmann constant $\left(\frac{\mathrm{W}}{\mathrm{m}^{2} \cdot \mathrm{K}^{4}}\right), T_{\text {surr }}$, surrounding temperature $\left({ }^{\circ} \mathrm{C}\right), T_{\text {sol-air }}$, solar-air temperature $\left({ }^{\circ} \mathrm{C}\right)$.

The equivalent changes of ambient temperature corresponding to the radiation correction are presented at the last term of Equation (4). The value is 0 for a vertical wall and it changes up to $4.0^{\circ} \mathrm{C}$ based on the inclination of the surface [35]. Total heat transfer coefficient for radiation (long wave) and convection $\left(h_{0}\right)$ were estimated by the IDA indoor climate and energy (IDA-ICE) processor. The values were generated for each hour during a year. The average of $h_{0}$ was $12.9 \mathrm{~W} / \mathrm{m}^{2} \cdot \mathrm{K}$, which was varied from 10.8 to $16.4 \mathrm{~W} / \mathrm{m}^{2} \cdot \mathrm{K}$ for the reference case. Also, a diversity of $h_{0}$ values was found for different climates. The solar radiation absorptivity was 0.5 in all cases. $q_{\text {solar }}$, the solar irradiance on the external opaque (vertical) surfaces, was calculated from all four directions and the average value was used. In the solar-air temperature calculation, there was no attempt to predict or take into account the solar radiation penetrating through the windows. Solar gains were calculated in the dynamic simulation, but window properties do not have any effect in the solar-air temperature calculation.

To consider the climatic impact on the insulation properties selection, economic insulation thickness was estimated according to the heating degree days with the following equation [36]:

$$
K_{v}=a_{n}\left(K_{R}+K_{T}\right) s+K_{H}+\frac{\lambda h_{L} H_{D D}}{s}
$$

where, $K_{v}$, annual cost of the wall $\left(\frac{€}{\mathrm{~m}^{2} \cdot \mathrm{a}}\right), a_{n}$, annuity factor $(-), K_{R}$, unit construction (investment) cost for building $\left(\frac{€}{\mathrm{~m}^{3}}\right), K_{T}$, unit real estate value $\left(\frac{€}{\mathrm{~m}^{3}}\right), s$, insulation material thickness $(\mathrm{m}), K_{H}$, maintenance cost $\left(\frac{€}{\mathrm{~m}^{2} \cdot \mathrm{a}}\right), \lambda$, conductivity of the material $\left(\frac{\mathrm{W}}{\mathrm{m} \cdot \mathrm{K}}\right), H_{D D}$, heating degree days $\left({ }^{\circ} \mathrm{Cd}\right)$, $h_{L}$, heating energy $\operatorname{cost}\left(\frac{€}{\mathrm{kWh}}\right)$.

Annual cost for the wall $\left(K_{v}\right)$ consists of the construction cost (of the wall), heating energy cost, space cost (affected by the wall thickness), and maintenance cost. All these cost terms depend on the insulation layer thickness. Based on the lowest annual cost, the optimal insulation thickness can be selected. In other words, the optimal insulation is the thickness of the insulation material that will give the lowest possible annual wall cost. To derive the equation of the optimal insulation thickness, only the thermal resistance $(R)$ of the insulation layer was taken into account. This simplification was needed to obtain the analytical solution. Finally, the square root dependency of degree days was used to convert insulation thicknesses from one climate to another. This justified the approach, as this study were not interested on an exact $U$ value (depending on costs) but rather in how the $U$ value changes as a function of degree days. The minimum of the annual cost of the wall depending on the insulation thickness can be found by setting the derivative to zero:

$$
\begin{gathered}
\frac{\partial K_{v}}{\partial s}=0 \\
\frac{\partial K_{v}}{\partial s}=a_{n}\left(K_{R}+K_{T}\right)-\frac{\lambda h_{L} H_{D D}}{s^{2}}=0 \\
U_{o p t}=\frac{\lambda}{s}=\sqrt{\frac{a_{n}\left(K_{R}+K_{T}\right) \lambda}{h_{L} H_{D D}}}=C \sqrt{\frac{1}{H_{D D}}} \text { where, } C=\sqrt{\frac{a_{n}\left(K_{R}+K_{T}\right) \lambda}{h_{L}}}
\end{gathered}
$$




$$
\begin{gathered}
U_{o p t}^{r e f}=C \sqrt{\frac{1}{H_{D D^{r e f}}}} ; U_{o p t}^{j}=C \sqrt{\frac{1}{H_{D D^{j}}}} \\
U_{o p t}^{r e f}=U_{o p t}^{j} \sqrt{\frac{H_{D D^{j}}}{H_{D D^{r e f}}}}
\end{gathered}
$$

where, $U_{o p t}$, optimal thermal transmittance $\left(\frac{\mathrm{W}}{\mathrm{m}^{2} \cdot \mathrm{K}}\right), U_{o p t}^{\text {ref }}$, optimal thermal transmittance of reference building $\left(\frac{\mathrm{W}}{\mathrm{m}^{2} \cdot \mathrm{K}}\right), U_{o p t}^{j}$, optimal thermal transmittance of respective building $\left(\frac{\mathrm{W}}{\mathrm{m}^{2} \cdot \mathrm{K}}\right), H_{D D}$, heating degree days $\left({ }^{\circ} \mathrm{Cd}\right), H_{D D^{\text {ref }}}$, Heating degree days for the reference (Estonian) office building $\left({ }^{\circ} \mathrm{Cd}\right)$, $H_{D D^{j}}$, Heating degree days for respective building $\left({ }^{\circ} \mathrm{Cd}\right), \mathrm{C}$, constant (-).

The reference building used in this study was the Estonian cost optimal calculation reference office building, described in [28]. It was assumed that the thermal transmittance ( $U$ value) of the reference building components was optimal, because it delivered a cost optimal energy performance for this Estonian office building. This assumption allowed us to apply Equation (10) with Estonian $U$-values to calculate $U$-values in other climate regions, which results can be seen in Table 6 . Because of the known optimal $U$-values of the reference building in Estonian climate, all cost related factors, i.e., annuity factor, construction cost, real estate value and maintenance cost were not needed in the analyses.

\subsection{Normalized Space Heating and Cooling Needs}

Normalization factors were calculated from the climate files. The base temperature was the only building specific data needed. The objective of the normalization factors is to normalize the space heating and cooling need from one climate to another. The method works if the normalized result equals to space heating and cooling need that is simulated in the other climate. Both dry-bulb outdoor air and solar-air temperature were used to calculate the heating degree days and dry bulb outdoor air temperature to calculate the cooling degree days reported in Table 7. These Degree days $(D D)$ were applied in Equation (11) to normalize the heating and cooling need to other climates:

$$
E_{j, N o r m}=E_{j} \cdot \frac{D D_{r e f}}{D D_{j}}
$$

where, $E_{j, \text { Norm }}$, normalized energy (space heating or cooling) need in the reference climate $\left(\frac{\mathrm{kWh}}{\mathrm{m}^{2} \cdot \mathrm{a}}\right)$, $E_{j}$, energy (space heating or cooling) need in the actual climate $\left(\frac{\mathrm{kWh}}{\mathrm{m}^{2} \cdot \mathrm{a}}\right), D D_{r e f}$, heating or cooling degree days in reference climate with dry-bulb air temperature or sol-air temperature $\left({ }^{\circ} \mathrm{Cd}\right), D D_{j}$, heating or cooling degree days in the actual climate with dry-bulb air temperature or solar-air temperature $\left({ }^{\circ} \mathrm{Cd}\right)$.

If economic insulation thickness is applied, the same cost-benefit justified economic effort is done in insulation in all climates, which should represent equal energy performance in all countries. However, space heating needs naturally are smaller in warmer climates, despite the use of economic insulation thicknesses. The ratio of the space heating need in the case of economic insulation thickness can be used in the comparison of energy requirements:

$$
H N \text { ratio }=\frac{H N_{R e f, E U}}{H N_{j, E U}}
$$

where, $H N$ ratio, space heating need ratio (-), $H N_{R e f, E U}$, space heating need in reference climate of EU case $\left(\frac{\mathrm{kWh}}{\mathrm{m}^{2} \cdot \mathrm{a}}\right), H N_{j, E U}$, space heating need in actual climate of EU case $\left(\frac{\mathrm{kWh}}{\mathrm{m}^{2} \cdot \mathrm{a}}\right)$.

\subsection{National Energy Performance Requirements for 2016 and 2021}

The maximum primary energy (PE) requirement for office buildings is set in all countries. France and Belgium Brussels capital region have already enforced NZEB regulations for office buildings [32,37,38] whereas Finland, Estonia have different PE requirement for 2016 and 2021 
NZEB [39]. Numerical PE indicator in $\mathrm{kWh} /\left(\mathrm{m}^{2} \cdot \mathrm{a}\right)$ is either a fixed value or depends on location, altitude and some other parameters, Table 1. Furthermore, the inclusion of energy flows are not similar for all countries. The PE indicators are calculated with national primary energy factors from delivered and exported energy and they may not include all energy uses in the building. For instance, in Finland energy calculation includes all energy flows (uses) in the building. National requirements are shown in Tables 1 and 2.

Table 1. The PE indicator national requirements and energy flows included for office buildings, according to the national regulations.

\begin{tabular}{|c|c|c|c|}
\hline \multirow[t]{2}{*}{ Country or Region } & \multirow{2}{*}{$\begin{array}{l}\text { Energy Flows } \\
\text { Excluded }\end{array}$} & \multicolumn{2}{|c|}{$\begin{array}{l}\text { Office Buildings Primary Energy Requirement } \\
\qquad \mathrm{kWh} /\left(\mathrm{m}^{2} \cdot \mathrm{a}\right)\end{array}$} \\
\hline & & 2016 & NZEB \\
\hline Finland [29] & - & 190 & 100 \\
\hline Estonia $[30,31]$ & - & 160 & 100 \\
\hline France [32] & Appliances & \multicolumn{2}{|c|}{$\begin{array}{c}50 M_{c, \text { type }}\left(M_{c, \text { geo }}+M_{c, \text { alt }}+M_{c, \text { surf }}+M_{c, \text { ges }}\right)^{2} \\
110^{4}\end{array}$} \\
\hline Brussels Capital region $[33,34]$ & Appliances, DHW & \multicolumn{2}{|c|}{$\begin{array}{c}95-(2,5 C) \text { or } 95-(2.5 C)+1.2 .(X-15)^{3} \\
88.2^{4}\end{array}$} \\
\hline
\end{tabular}

1 Energy flows considered are heating, ventilation, cooling, DHW, auxiliary, lighting and appliances. 2 Depending on building type and category coefficient $\left(M_{c, \text { type }}\right)$, geographical location coefficient $\left(M_{c, \text { geo }}\right)$, altitude coefficient $\left(M_{c, a l t}\right)$, commercial buildings floor surface coefficient $\left(M_{c, s u r f}\right)$, and greenhouse potential of the fuel used coefficient $\left(M_{c, g e s}\right) .{ }^{3}$ If space heating $X<15.0 \mathrm{kWh} / \mathrm{m}^{2}$ a then use this equation $95-(2,5 C)$ where ' $C^{\prime}$ denotes compactness. Depending on net needed energy for heating. ${ }^{4}$ The requirement value for the reference building used in this study.

Table 2. The primary energy factor (PE factor) according to the national regulations.

\begin{tabular}{ccccccccc}
\hline Regulation & \multicolumn{2}{c}{ Finland [29] } & \multicolumn{2}{c}{ Estonia [30,31] } & \multicolumn{2}{c}{ France [32] } & \multicolumn{2}{c}{ Brussels Capital Region [33,34] } \\
\hline Energy Carrier & $\mathbf{2 0 1 6}$ & NZEB & $\mathbf{2 0 1 6}$ & NZEB & $\mathbf{2 0 1 6}$ & NZEB & $\mathbf{2 0 1 6}$ & NZEB \\
\hline Electricity & 1.7 & 1.2 & 2.0 & 2.0 & 2.58 & 2.58 & 2.5 & 2.5 \\
District heating & 0.7 & 0.5 & 0.9 & 0.9 & 1.0 & 0.88 & 2.0 & 2.0 \\
Natural gas & 1.0 & 1.0 & 1.0 & 1.0 & 1.0 & 1.0 & 1.0 & 1.0 \\
\hline
\end{tabular}

According to the national regulations, the Finnish and Estonian office buildings have to comply with fixed PE value (Table 1), which are not dependent on the geometry and location of offices. In contrast, the French regulation considers a coefficient depending the floor surface area $\left(M_{\mathcal{c}_{\text {surf }}}\right)$ that can influence the PE requirement [32]. However, the coefficient is zero when it is considered as the average surface area of the building or part of the building [32]. The Belgium Brussels capital regulation accounts for net heated area, heat loss area and compactness (depending on region) to determine the PE requirement.

\subsection{EC Official Recommendations for 2021 NZEB Primary Energy}

European Commission official recommendations, EU 2016/1318 [27], recommend that NZEB energy performance levels for new buildings have to be determined by the best available technology introduced on the market at that time, financial aspects, and legal and political considerations at a national level. In order to make its proper ambitions transparent, the EC has set numerical benchmarks for NZEB primary energy use in four climate zones (Table 3).

Net primary energy is the primary energy from which on-site renewable energy is reduced. Default values of on-site renewables are also provided. For example, the office building value in Nordic climate 55-70 is achieved when from primary energy without on-site renewable energy source (RES) 85-100 the on-site renewable energy source (RES) 30 is subtracted. It is important to note that EC values in Table 3 do not include the appliances (small power loads), which are included in the 
Finnish and Estonian requirements, and therefore these are needed to be taken into account when comparing values.

Table 3. Numeric benchmarks for NZEB primary energy use in office buildings set by the EC recommendations EU 2016/1318.

\begin{tabular}{ccccc}
\hline EC Recommendation & $\begin{array}{c}\text { Mediterranean } \\
\text { Zone 1: Catania, } \\
\text { Athens, Larnaca, } \\
\text { Luga, Seville, } \\
\text { Palermo }\end{array}$ & $\begin{array}{c}\text { Zone 4: Paris, Amsterdam, } \\
\text { Berlin, Brussels, } \\
\text { Copenhagen, Dublin, } \\
\text { London, Prague, Warszawa }\end{array}$ & $\begin{array}{c}\text { Continental } \\
\text { Zone 3: Budapest, } \\
\text { Bratislava, } \\
\text { Ljubljana, Milan, } \\
\text { Vienna }\end{array}$ & $\begin{array}{c}\text { Nordic } \\
\text { Zone 5: Stockholm, } \\
\text { Tallinn, Helsinki, } \\
\text { Riga, Stockholm, } \\
\text { Gdansk, Tovarene }\end{array}$ \\
\hline $\begin{array}{c}\text { Primary energy } \\
\text { without RES, } \\
\mathrm{kWh} /\left(\mathrm{m}^{2} \cdot \mathrm{a}\right)\end{array}$ & $80-90$ & $85-100$ & $85-100$ & $85-100$ \\
\hline $\begin{array}{c}\text { On-site RES sources, } \\
\mathrm{kWh} /\left(\mathrm{m}^{2} \cdot \mathrm{a}\right)\end{array}$ & 60 & 45 & 45 & 30 \\
\hline $\begin{array}{c}\text { Net primary energy } \\
\mathrm{kWh} /\left(\mathrm{m}^{2} \cdot \mathrm{a}\right)\end{array}$ & $20-30$ & $40-55$ & $40-55$ & $55-70$ \\
\hline
\end{tabular}

As a starting point, national NZEB requirements can be directly compared with EC recommendations as shown in Figure 2. For Estonia and Finland, the contribution of appliances was deducted from the NZEB requirement shown in Figure 2 to be comparable with the EC recommendation.

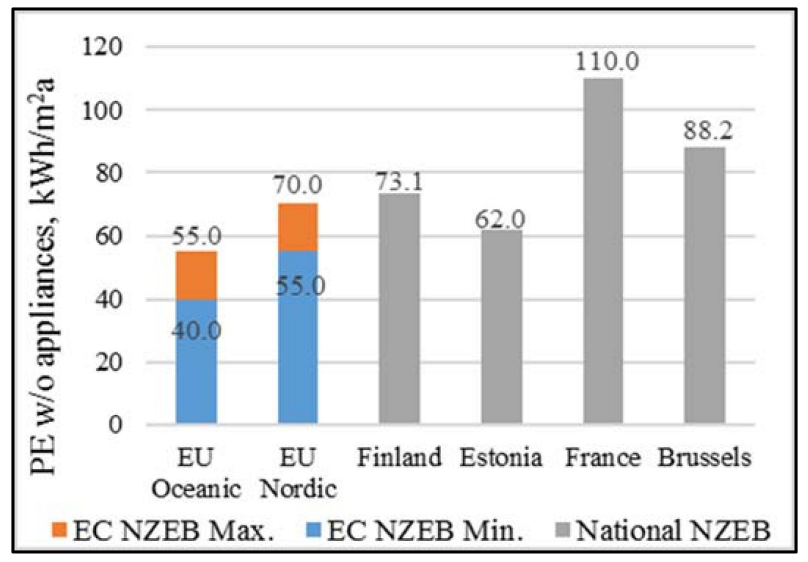

Figure 2. The compliance of national NZEB requirements with EC recommendations, a direct comparison without taking into account national input data and primary energy factors differences.

\subsection{The Reference Office Building}

Dynamic whole-year simulations were conducted with the well validated indoor climate and energy simulation tool IDA-ICE v4.7, developed by EQUA Simulations AB [40]. A cost-optimal Estonian reference office building (Figure 3) with multiple floors and zones was used. This building is generally well insulated, equipped with heat recovery and air conditioning, the main parameters are reported in Tables 4 and 5 .

The building had a massive concrete loadbearing frame and structure. The external walls were lightweight with mineral wool, and thin boards. The external roof, floor slab, and internal ceilings were reinforced concrete slabs. The net floor area, envelope area, and window area of the reference office building model were $4451.8 \mathrm{~m}^{2}, 3993.9 \mathrm{~m}^{2}$ and $1326 \mathrm{~m}^{2}$, respectively. The thermal transmittance of internal floor (inside), external floor, internal wall, and entrance door were $0.24,0.13,0.30,1.5 \mathrm{~W} /\left(\mathrm{m}^{2} \cdot \mathrm{K}\right)$ in all cases.

The building was well insulated and thermal bridges were formed only due to the building geometry. The thermal bridge of external wall to internal slab, external wall to external 
wall, roof to external wall, external slab to external walls, roof to internal wall were $0.06,0.03,0,05$, $0.05,0.025 \mathrm{~W} / \mathrm{mK}$, respectively. The thermal bridge for external windows perimeter was $0.024 \mathrm{~W} / \mathrm{mK}$. Thermal bridges accounted around $9 \%$ of the total heat losses. Solar energy transmittance of windows ( $g$ value) was kept the same, $g=0.22$ for all climates and buildings of 2016 and NZEB. The building leakage rate was $1.01 / \mathrm{h}$ at a pressure difference of $50 \mathrm{~Pa}$ for all cases.

Installed power of lighting and appliances and energy needs for domestic hot water (DHW) were taken from national regulations. References [30-32,41] were used to extract information for Finland, Estonia, and France, respectively. Lighting for Belgium Brussels was estimated from [42]. Lighting power for 2016 followed the code values of Estonia, Finland and France. More efficient lighting of $8.0 \mathrm{~W} / \mathrm{m}^{2}$ instead of $20 \mathrm{~W} / \mathrm{m}^{2}$ was considered for Brussels. For 2021, light-emitting diode (LED) dimmable lighting fixture with daylight control were used for Estonia and Finland. France and Brussels kept the same lighting power as 2016. In France and Belgium Brussels regulation, energy need for appliances are not included in energy flows when calculating PE value [39]. The generation efficiency for cooling was 3.0. Radiator heating efficiency of $97 \%$, district heating generation efficiency $100 \%$, condensing gas boiler generation efficiency of $95 \%$ and cooling system losses of $10 \%$ were accounted in simulation. These properties were kept the same for all 2016 and NZEB simulation cases. In contrast, the specific fan power (SFP) was assumed to be 1.82 and $1.56 \mathrm{~kW} /\left(\mathrm{m}^{3} / \mathrm{s}\right.$ ) for 2016 building and NZEB, respectively. Similarly, the heat recovery efficiency was $73.9 \%$ and $76.1 \%$. Onsite installed solar panel system was $48 \mathrm{~m}^{2}$ per $1000 \mathrm{~m}^{2}$ of net floor area for the NZEB building only.
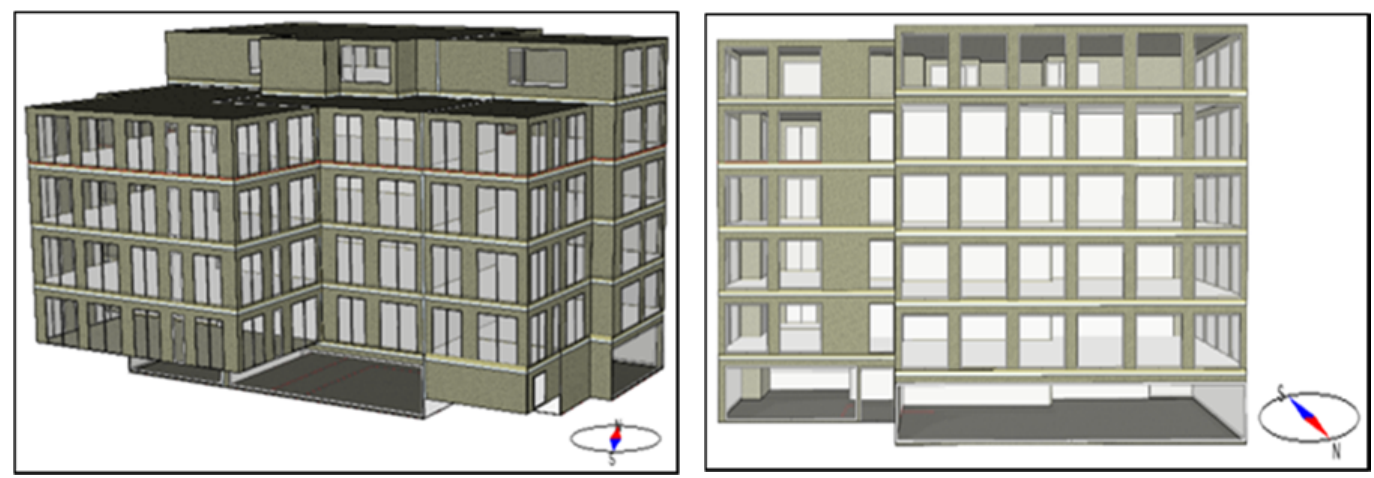

Figure 3. 3D model of simulated reference office building.

\section{Analyzed Cases and Energy Calculation Input Data}

Energy performance was simulated with standard and national input data while the reference office building was moved from one to another climate region. Four cases were simulated both for 2016 and 2021 NZEB energy requirements as shown in Table 4. EU cases used the standard prEN 16798-1:2017 [43] input data, whereas NAT (national) cases the national input data. $\mathrm{EU}_{\text {na }}$ and $\mathrm{NAT}_{\text {na }}$ cases represent the situation where Estonian insulation thickness was applied to other countries, which means clearly over-insulating in France and Belgium. EU and NAT cases applied economic insulation thickness to avoid this problem.

Table 4. Description of four simulated cases.

\begin{tabular}{cc}
\hline Code & Case Description \\
\hline EUna $_{\text {na }}$ & prEN 16798-1 input data, insulation thickness not adjusted (the same in all countries) \\
NAT $_{\text {na }}$ & National input data, insulation thickness not adjusted (the same in all countries) \\
NAT & Economic insulation and national input data \\
EU & Economic insulation and prEN 16798-1 input data \\
\hline
\end{tabular}


Energy calculation input data is shown in Table 5. For EU prEN 16798-1:2017 standard data, indoor climate category II values were used. The EU occupancy and operation values correspond to a landscape office and ventilation rate is determined by a single office. Installed power of lighting and DHW consumption data are not given in prEN 16798-1:2017 and are intended to be calculated with other standards, but for simplicity best practice values for lighting and Finnish/Estonian DHW value are used.

Table 5. prEN 16798-1:2017 and national energy calculation input data, and ISO 52000-1:2017 and national 2021 primary energy (PE) factors.

\begin{tabular}{cccccc}
\hline Factor & EU & Finland & Estonia & France & Brussels \\
\hline Occupant, $\mathrm{m}^{2} /$ person & 17 & 17 & 17 & 10 & 15 \\
Appliances, $\mathrm{W} / \mathrm{m}^{2}$ & 12 & 12 & 12 & 5.7 & 3 \\
Lighting, $\mathrm{W} / \mathrm{m}^{2}$ & 6 & 6 & 6 & 8 & 9.8 \\
Appliances \& lighting operation hour & $7: 00-18: 00$ & $7: 00-18: 00$ & $7: 00-18: 00$ & $8: 00-18: 00$ & $8: 00-18: 00$ \\
Usage factor & 0.55 & 0.65 & 0.55 & 0.6 & 0.6 \\
Hot water consumption, Liter $/ \mathrm{m}^{2} \cdot \mathrm{a}$ & 100 & 100 & 100 & 65 & 0 \\
Fan operation hour & $: 00-19: 00$ & $6: 00-19: 00$ & $6: 00-19: 00$ & $6: 00-19: 00$ & $6: 00-19: 00$ \\
Ventilation rate, Liter $/ \mathrm{m}^{2} \cdot \mathrm{s}$ & 1.4 & 2.0 & 2.0 & 0.5 & 1.2 \\
Heating set point, ${ }^{\circ} \mathrm{C}$ & 21 & 21 & 21 & 20 & 19 \\
Cooling set point, ${ }^{\circ} \mathrm{C}$ & 25 & 25 & 25 & 26 & 23 \\
PE factor for electricity & 2.3 & 1.2 & 2.0 & 2.58 & 2.5 \\
PE factor for gas & 1.1 & 1.0 & 1.0 & 1.0 & 1.0 \\
PE factor for district heat & 1.3 & 0.5 & 0.9 & 0.88 & 2.0 \\
\hline
\end{tabular}

Energy need was simulated according the hourly weather data in all countries. Insulation thickness and $U$-values are shown in Table 6.

Table 6. Building insulation thickness and $U$-values in EU and NAT cases.

\begin{tabular}{ccccccccc}
\hline Country & \multicolumn{2}{c}{ Finland } & \multicolumn{2}{c}{ Estonia $^{\mathbf{1}}$} & \multicolumn{2}{c}{ France } & \multicolumn{2}{c}{ Belgium Brussels } \\
\hline Building element & 2016 & NZEB & 2016 & NZEB & 2016 & NZEB & 2016 & NZEB \\
External wall, $\mathrm{m}$ & 0.174 & 0.205 & 0.17 & 0.20 & 0.106 & 0.125 & 0.115 & 0.135 \\
Roof, $\mathrm{m}$ & 0.256 & 0.308 & 0.25 & 0.30 & 0.157 & 0.188 & 0.169 & 0.20 \\
External wall, $\mathrm{W} /\left(\mathrm{m}^{2} \cdot \mathrm{K}\right)$ & 0.196 & 0.168 & 0.20 & 0.17 & 0.312 & 0.268 & 0.289 & 0.25 \\
Roof, $\mathrm{W} /\left(\mathrm{m}^{2} \cdot \mathrm{K}\right)$ & 0.132 & 0.111 & 0.13 & 0.11 & 0.207 & 0.175 & 0.193 & 0.166 \\
Window glazing unit, $\mathrm{W} /\left(\mathrm{m}^{2} \cdot \mathrm{K}\right)$ & 0.609 & 0.607 & 0.62 & 0.62 & 1.007 & 1.007 & 0.927 & 0.935 \\
Window $10 \%$ frame $\mathrm{W} /\left(\mathrm{m}^{2} \cdot \mathrm{K}\right)$ & 0.748 & 0.646 & 0.76 & 0.66 & 1.106 & 1.006 & 1.034 & 0.942 \\
Window 30 $\%$ frame, $\mathrm{W} /\left(\mathrm{m}^{2} \cdot \mathrm{K}\right)$ & 0.876 & 0.725 & 0.89 & 0.74 & 1.155 & 1.005 & 1.099 & 0.955 \\
\hline
\end{tabular}

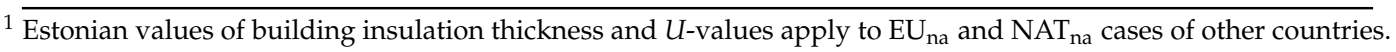

\section{Results and Discussion}

\subsection{Degree Days and Base Temperature}

Base temperature depends on the dry bulb temperature, internal and solar heat gains, and building properties. It was estimated as a constant value at which the reference office building begins to need space heating or cooling. A dynamic whole year simulation was ran with IDA-ICE in order to determine the outdoor temperature (base temperature for heating) at which the building demanded heating power. A similar procedure was followed to obtain the base temperature for cooling. The plots of heating and cooling powers used for the base temperature estimation of the reference office building 2016 in Estonian climate are shown in Figure 4.

The base temperature changed when the building was moved from one to another climate region. For heating, it ranged from $12-15{ }^{\circ} \mathrm{C}$ and for cooling from $14-16^{\circ} \mathrm{C}$. Degree days were calculated from hourly temperatures as a difference of ambient and the base temperature and then summed as the cumulative value of all positive values. Base temperatures were used to calculate the heating and cooling degree days from dry-bulb and solar-air temperature (Table 7). 


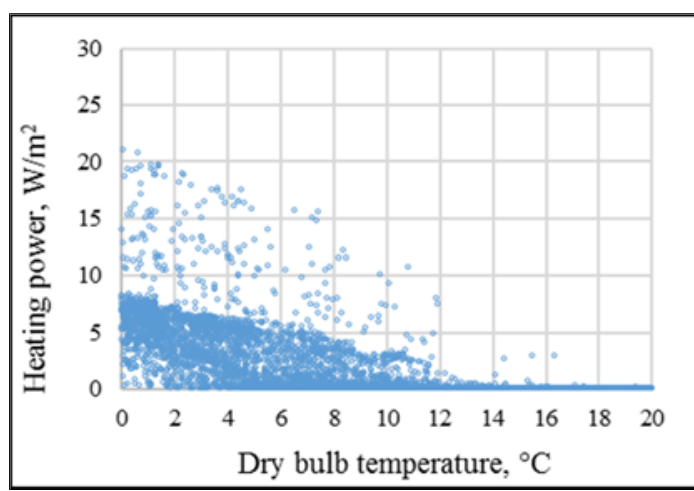

(a)

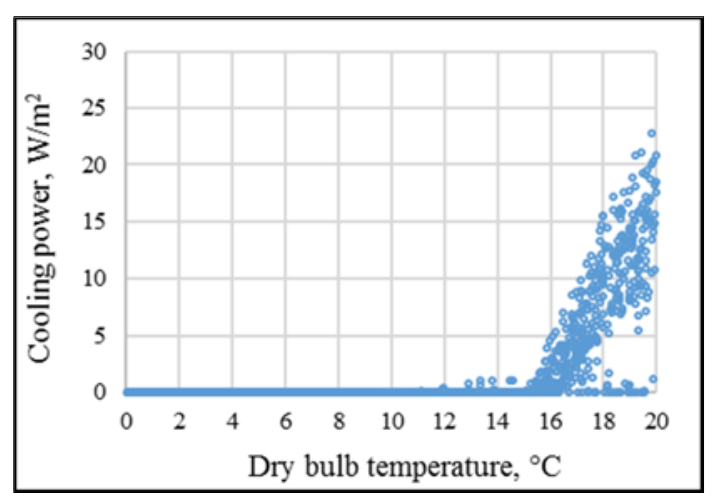

(b)

Figure 4. Base temperature selection for reference office building 2016 in Estonian climate (a) space heating and (b) cooling.

Table 7. Base temperature for heating, cooling and respective heating degree days and cooling degree days.

\begin{tabular}{ccccc}
\hline Base Temperature & Estonia & Finland & France & Belgium \\
\hline Heating base tem.-2016, ${ }^{\circ} \mathrm{C}$ & 13 & 13 & 15 & 15 \\
Heating degree days-2016 (Solar-air), ${ }^{\circ} \mathrm{Cd}$ & 2304 & 2412 & 971 & 1134 \\
Heating degree days-2016 (Dry-bulb), ${ }^{\circ} \mathrm{Cd}$ & 2900 & 2955 & 1650 & 1799 \\
Heating base tem.-2021, ${ }^{\circ} \mathrm{C}$ & 12 & 12 & 14 & 14 \\
Heating degree days-2021 (Solar-air), ${ }^{\circ} \mathrm{Cd}$ & 2092 & 2200 & 820 & 952 \\
Heating degree days-2021 (Dry-bulb), ${ }^{\circ} \mathrm{Cd}$ & 2627 & 2682 & 1424 & 1542 \\
Cooling base tem.-2016, ${ }^{\circ} \mathrm{C}$ & 14 & 14 & 15 & 15 \\
Cooling degree days-2016 (Dry-bulb), ${ }^{\circ} \mathrm{Cd}$ & 271 & 289 & 586 & 363 \\
Cooling base tem.-2021, ${ }^{\circ} \mathrm{C}$ & 15 & 15 & 16 & 16 \\
Cooling degree days-2021 (Dry-bulb), ${ }^{\circ} \mathrm{Cd}$ & 180 & 199 & 434 & 248 \\
\hline
\end{tabular}

\subsection{Heating and Cooling Energy Normalization Accuracy in Different Climates}

The energy performance of buildings located in different climates can be compared with degree day normalization if space heating, cooling and lighting energy uses are known and the occupancy patterns are similar. In the following, the accuracy of the normalization factors calculated from climate files is analyzed. The only building-specific data is the base temperature for heating and cooling. To test the accuracy, the reference office buildings with standard input data and national weather files, the cases $\mathrm{EU}_{\text {na }}$ in Table 4, were simulated. Space heating and cooling need were normalized with Equation (11) to the Estonian climate that considers both dry-bulb temperature and solar-air temperature, the actual and normalized space heating need are shown in Figure 5.

After normalization with $D D$ (from dry-bulb temperature in Figure 5a), the space heating needs should be the same in all climates. In the case of France and Brussels having smaller HDD, heating needs showed up to $35 \%$ of variations compared to the Estonian case. Normalization with $D D$ from solar-air temperature worked more precisely (Figure $5 b$ ), providing $2 \%$ accuracy for 2021 and 15\% accuracy for 2016. Therefore, the use of solar-air temperature showed clearly superior performance.

The normalization of cooling energy was split into two components because the cooling coil energy in the air handling unit (AHU) depends only on the outdoor air enthalpy, but the space cooling (room conditioning units) depends on outdoor temperature and solar radiation. Actual and normalized cooling needs for AHU cooling coil and space cooling are shown in Figures 6 and 7. 


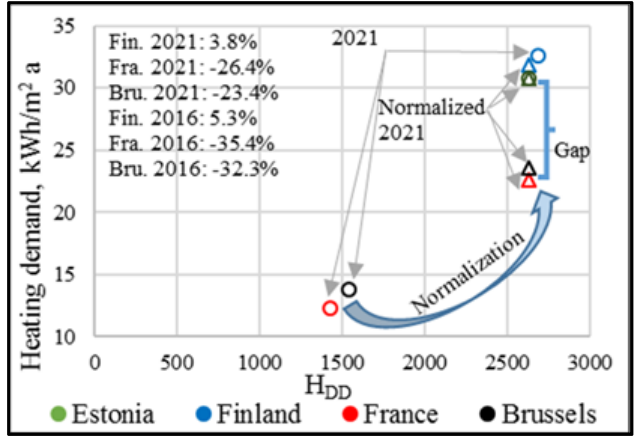

(a)

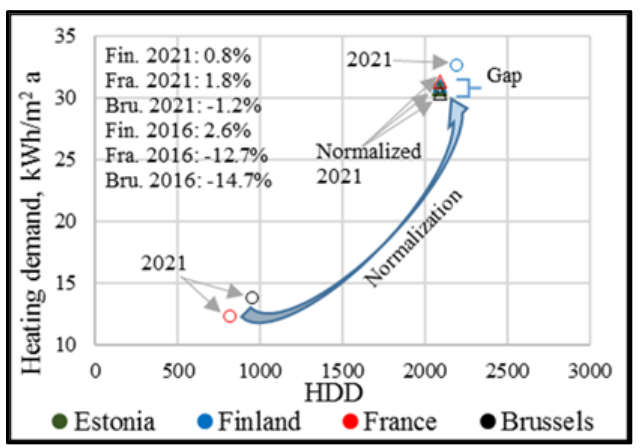

(b)

Figure 5. Actual and normalized space heating needs to Estonian climate for different countries (a) With dry-bulb temperature (only 2021 data shown); (b) With solar-air temperature (both 2016 and 2021 data shown). The \% values report the accuracy of normalization and the arrows show original and normalized values (o refers to 2021, $\Delta$ refers to normalized 2021). The colors of the marks used in the figures follow the color code provided in the legend.

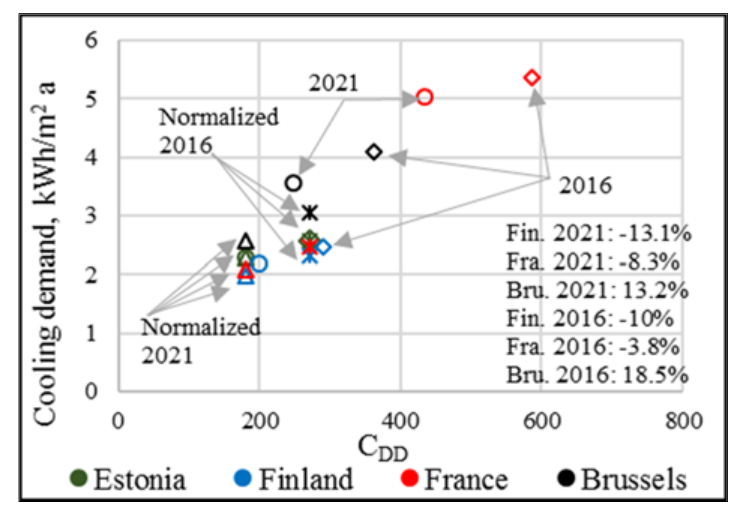

Figure 6. Actual and normalized cooling needs for AHU cooling coil with dry-bulb temperature degree days. The $\%$ values show the accuracy of normalization and the arrows show actual and normalized values (o refers to 2021, $\Delta$ refers to normalized 2021, $\diamond$ refers to 2016, refers to normalized 2016). The colors of the marks used in the figure follows the color code provided in the legend.

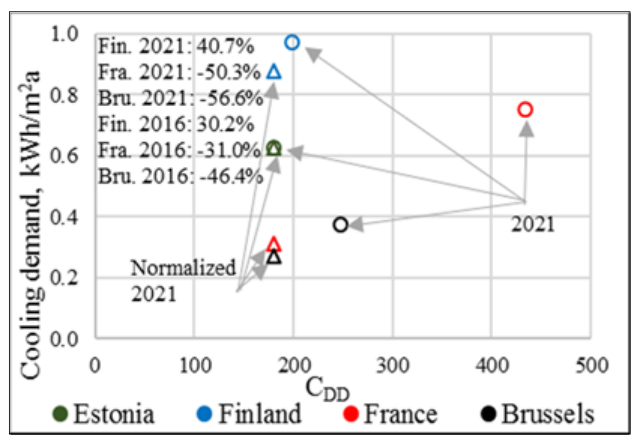

(a)

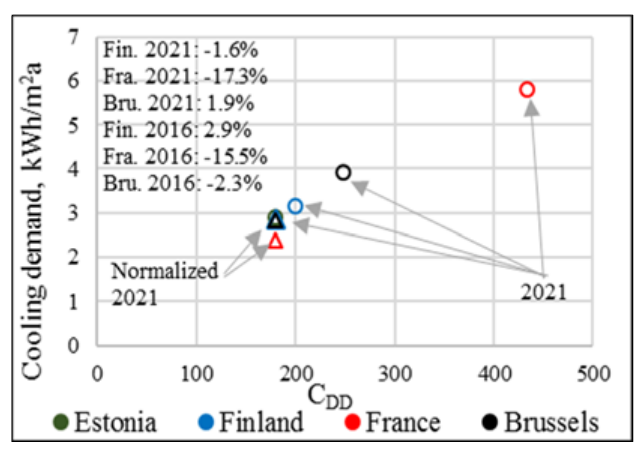

(b)

Figure 7. Actual and normalized cooling needs, (a) space cooling with dry-bulb temperature (b) space and AHU cooling (total) need with dry-bulb temperature. The \% values show the accuracy of normalization and the arrows show original and normalized values (o refers to 2021, $\Delta$ refers to normalized 2021). The colors of the marks used in the figures follow the color code provided in the legend. 
Results show that for AHU cooling coil the accuracy is from +19 to $-13 \%$, however the absolute difference was less than $1 \mathrm{kWh} /\left(\mathrm{m}^{2} \cdot \mathrm{a}\right)$. The accuracy for space cooling (Figure 7a) was less good, but absolute differences were smaller than $0.3 \mathrm{kWh} /\left(\mathrm{m}^{2} \cdot \mathrm{a}\right)$. As the cooling need of AHU cooling coil dominated over the space cooling, the normalization of total cooling need provided reasonably good accuracy with the absolute difference less than $1.0 \mathrm{kWh} /\left(\mathrm{m}^{2} \cdot \mathrm{a}\right)$ (Figure $7 \mathrm{~b}$ ). Thus, the splitting into two cooling energy components is not needed.

\subsection{Heating, Cooling and Lighting Normalization Factor}

The results in Figure 5 represent the situation where the same insulation thickness is considered to be used in all climates ( $\mathrm{EU}_{\mathrm{na}}$ cases). This evidently leads to over-insulating in the warmer climates of France and Belgium that makes the degree day method not useful for the comparison of buildings in strongly different climates. To overcome this problem, EU cases with economic insulation thickness were simulated.

The actual results in all countries (EU, without any correction) can be seen in Figure 9, where the space heating need has significantly increased in France and Belgium, but is still smaller than in Estonia and Finland. However, in these cases the same cost-benefit justified economic effort has been done in insulation, which allows to consider that energy performance should be equal in all countries.

The summary of all climate normalization factors of Sections 4.2 and 4.3 is shown in Table 8. Normalization factors represent the ratio $\left(D D_{r e f} / D D_{j}\right)$ in Equation (11). These factors may be used to obtain the energy needs for space heating, cooling and lighting in another country. For instance, if solar-air based factor is used to compare a Finnish building with the reference Estonian building, the Finnish space heating need should be multiplied by a factor of 0.95 . For a French building, space heating need needs to be multiplied by 2.55 . These factors apply with the same insulation in all countries except the space heating ratio, which considers economic insulation.

The space heating need ratio relative to the reference of Estonia was calculated for all countries with Equation (12) as an informative value without any specific application. These values just show how much space heating needs are smaller in warmer climate, if economic insulation is applied. It is important to note that these informative space heating need ratios are building specific, in principle those apply for the reference building only and this study cannot provide information how they may be generalized for other buildings. To generalize, the method needs to be tested with larger sample of buildings that is out of the scope of this study. This is the major difference to the normalization factors, which were calculated from climate files with the base temperature that was the only building specific parameter.

$\mathrm{EU}_{\text {na }}$ simulations for NZEB showed the lighting electricity differences with daylight control and dimmable LEDs for simulated climates that is also a building specific result applying only for the studied reference building.

Table 8. Summary of heating, cooling, and electric lighting normalization factors allowing to predict energy need in another climate.

\begin{tabular}{|c|c|c|c|c|}
\hline Normalization Factor & Estonia (ref) & Finland & France & Belgium Brussels \\
\hline $\begin{array}{l}\text { Solar-air temperature normalization space heating need } \\
\text { factor } H_{D D^{r e f}} / H_{D D^{j}}\end{array}$ & 1.00 & 0.95 & 2.55 & 2.20 \\
\hline $\begin{array}{l}\text { Dry-bulb air temperature normalization space heating need } \\
\text { factor } H_{D D^{s o l}, \text { ref }} / H_{D D^{s o l, j}}\end{array}$ & 1.00 & 0.98 & 1.84 & 1.70 \\
\hline $\begin{array}{c}\text { Space heating need ratio in the case of economic insulation } \\
\text { thickness (Equation (12)) }\end{array}$ & 1.00 & 0.95 & 1.58 & 1.52 \\
\hline $\begin{array}{l}\text { Dry-bulb temperature normalization cooling need } \\
\text { factor } C_{D D^{r e f}} / C_{D D^{j}}\end{array}$ & 1.00 & 0.90 & 0.41 & 0.73 \\
\hline${ }^{1}$ Normalization electric lighting factor & 1.00 & 0.95 & 1.32 & 1.23 \\
\hline
\end{tabular}




\subsection{Impact of National Input Values on Energy Use}

The input values of building operation, indoor climate and loads such as ventilation rate, system operation hours, temperature set points, installed lighting power, appliances, occupancy rate, etc. may play a crucial role in simulated energy use. The national input values from Table 5 were used in simulations to show the difference between EU and NAT cases (Figure 8).

For EU cases the variation of space heating and cooling is caused due to the climate variation. In Finland and Estonia only small changes can be seen, therefore input data of those countries is similar with the standard one. In France and Belgium, the national input values have caused remarkable changes in delivered energy. This is because the lower ventilation rate, shorter operation hour and different installed lighting and appliances power, which follow the French and Brussels capital regulation. Generally, it can be seen that national input data has caused more difference than the climate.

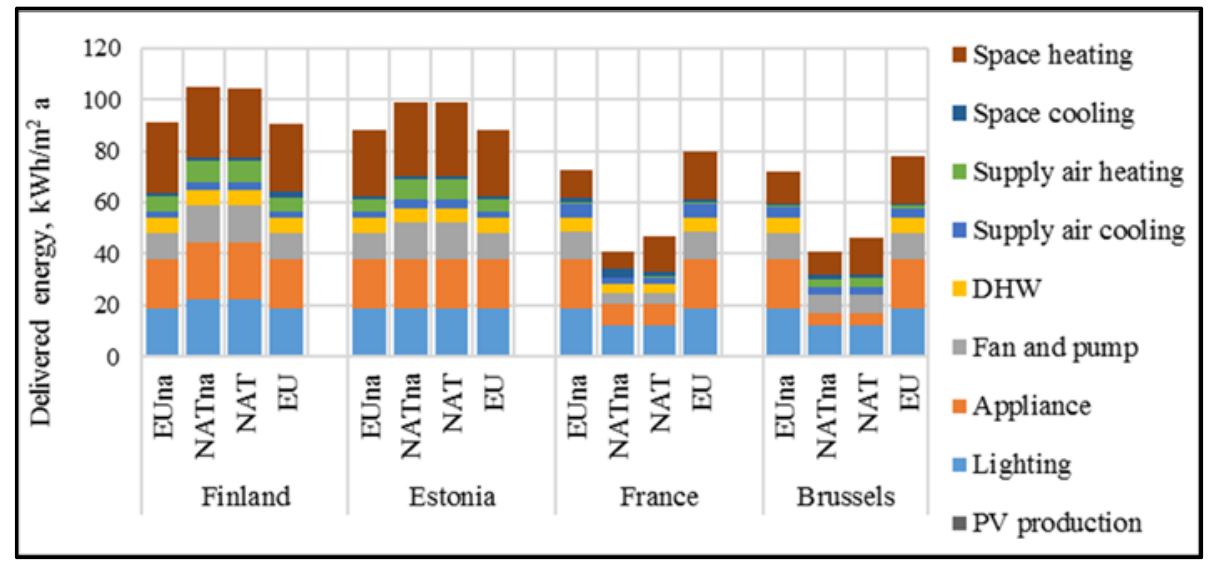

(a)

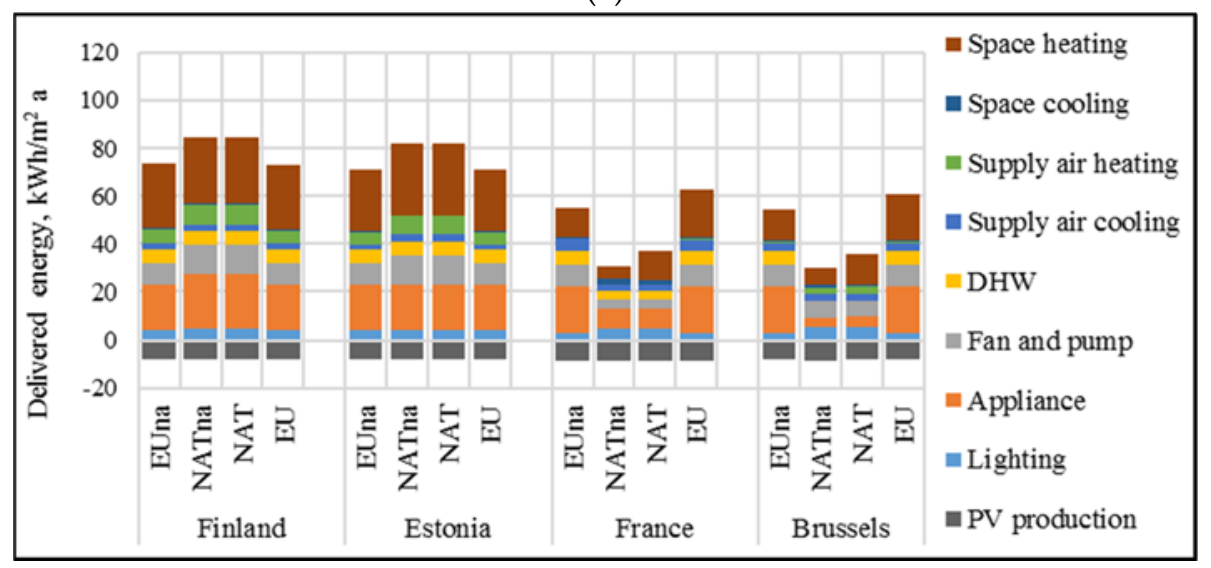

(b)

Figure 8. Comparison of delivered energy use in simulated cases with reference and national input values (a) 2016, (b) NZEB. PV production refers as onsite electricity production from the photovoltaic panel (PV).

\subsection{Ambition of National NZEB Requirements}

The NAT cases of all countries have economic insulation thickness as well as input values according to national regulation. The delivered energy reported in Figure 8 does not show the compliance with energy performance requirements because the requirements are for primary energy and PE factors are to be applied. PE use in office buildings for NAT cases are shown in Figure 9. 


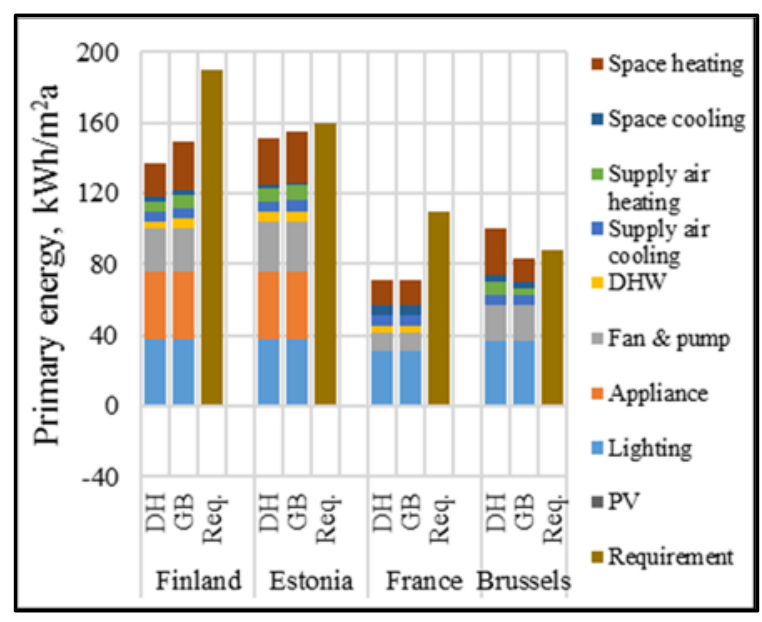

(a)

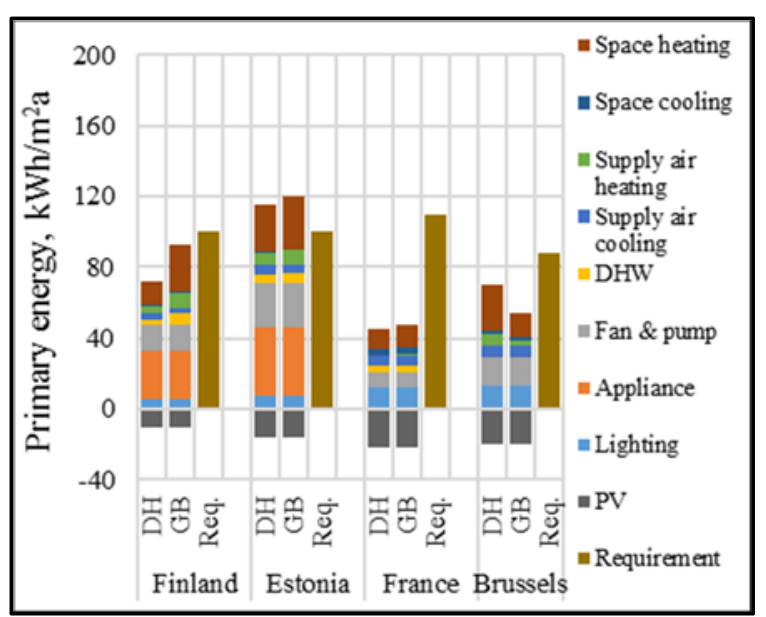

(b)

Figure 9. Primary energy in NAT cases office buildings compared with regulation (a) 2016, (b) 2021 NZEB.

DH refers to district heating, GB to gas boiler and Req. to minimum energy performance requirement in 2016 and 2021. In Figure 9b, onsite electricity production from the photovoltaic panel (PV) is marked with negative values. This PV production has to be deducted from positive values in order to obtain the primary energy value, which can be compared with the requirement. With 2016 regulation (Table 1), all buildings fulfilled the national requirement except Belgium Brussels office building with district heating due to very high primary energy factor 2.0 for $\mathrm{DH}$ (Table 2). In case of Estonian office building, the calculated PE is closest to the national requirement and the building just fulfills the requirement. The PE use in Finnish and French buildings is much lower indicating that national requirement is less strict.

The onsite PV was introduced to fulfill the NZEB requirements (Table 1). Due to the very strict primary energy requirement, onsite electricity production from PV panel was needed to fulfill the national requirement (Table 1). The Estonian NZEB requirement appeared the strictest one among the other building regulations as the Estonian building with a DH system just fulfilled the NZEB requirements whereas a building with GB needed to increase the onsite electricity production (PV panel area from 213 to $266 \mathrm{~m}^{2}$ ) to fulfill the NZEB requirements. For the other countries primary energy values were lower than the requirements, therefore, it was possible to change some building and system parameters in order to achieve closer compliance with NZEB requirement. The following changes were made:

- In Finland, Brussels and France the PV system was removed;

- In Finland the NZEB level was targeted with DH and in Brussels with a GB system, which are common heating solutions in these countries (due to lower primary energy factors these allow the use of more delivered energy);

- In Finland, 2016 building insulation, specific fan power, heat recovery efficiency, and glazing $U$ value $1.4 \mathrm{~W} / \mathrm{m}^{2} \cdot \mathrm{K}$ were applied;

- In Brussels and France, even less insulation was used, the $U$ value of external walls, roof and windows were changed to $0.6 \mathrm{~W} / \mathrm{m}^{2} \cdot \mathrm{K}, 0.4 \mathrm{~W} / \mathrm{m}^{2} \cdot \mathrm{K}$ and $2.0 \mathrm{~W} / \mathrm{m}^{2} \cdot \mathrm{K}$, respectively. For specific fan power and heat recovery efficiency, 2016 values were used;

- In France, additionally daylight control of lighting was removed.

The results after all these changes are shown in Figure 10. It can be seen that the Finnish NZEB requirement can be considered the second strictest after Estonia, because the result in Figure 9 is closer to the requirement than that in Brussels and less changes was needed for the closer compliance than in 
Brussels and France, Figure 10. The French NZEB regulation appeared the least strict as it allowed the use of lighting with no daylight control.

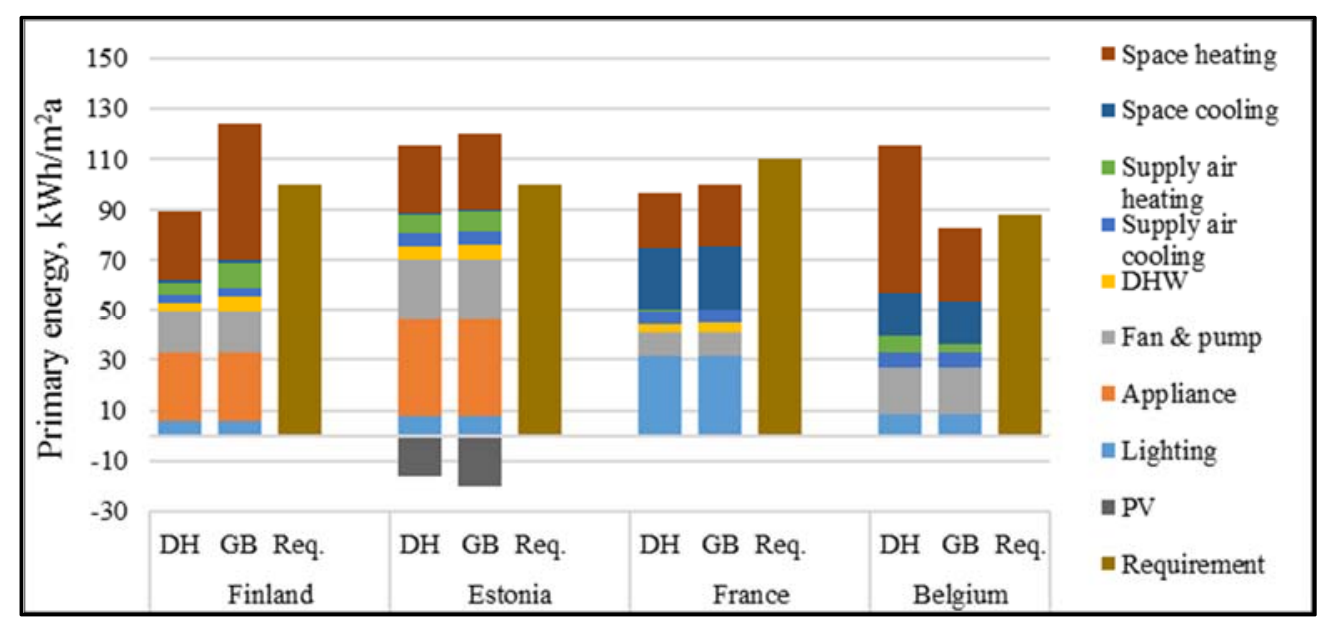

Figure 10. Primary energy in NZEB office buildings with changed parameters in order to target NZEB requirements.

Figure 10 represents buildings with technical solutions, which comply with less than $10 \%$ safety margin with the national NZEB requirements. Therefore, with these technical solutions the compliance of national NZEB requirements with EC recommendations (Table 3) can be analyzed by conducting simulations with EU energy calculation input data and primary energy factors (Table 5). Figure 11 shows the result calculated with prEN 16798-1 energy calculation input data and ISO 52000-1:2017 primary energy factors. While in the case of Estonia, France and Brussels the changes remained relatively small and appeared in both directions, the Finnish PE value was remarkably increased and is roughly by factor 2 higher than EC recommendation, which applies for the French PE value as well. This is evidently caused by the small Finnish primary energy factors revealing that the direct comparison done in Figure 2 is not working.

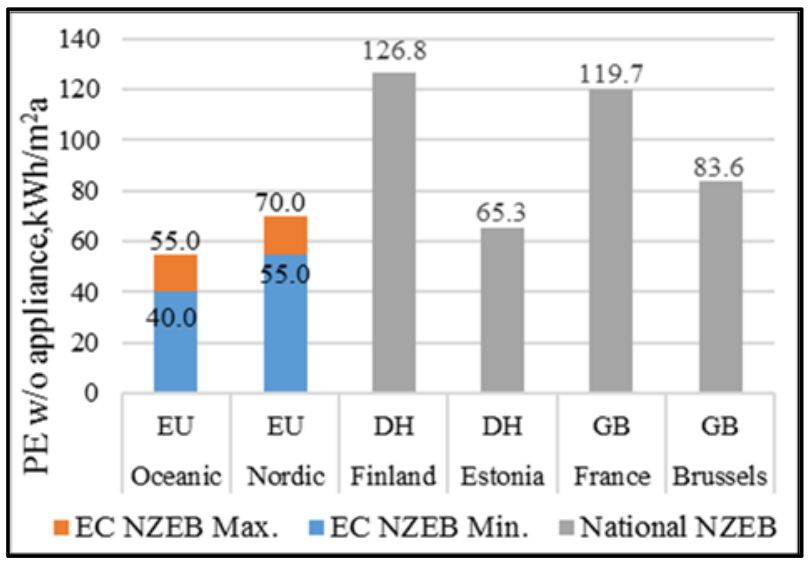

Figure 11. The compliance of national NZEB requirements with EC recommendations with prEN 16798-1 energy calculation input data and ISO 52000-1:2017 primary energy factors.

\section{Conclusions}

This study developed two energy performance climate correction methods enabling one to compare the energy performance of buildings located in different climates. The proposed normalization 
factors allow one to "move" a building from one climate to another with corresponding changes in space heating, cooling and electric lighting needs. However, normalization factors are limited to the same thermal insulation. To contrast the national energy performance requirements with realistic insulation, an economic insulation method with a reference building was developed. To perform the comparison, a reference office building with economic insulation thickness and otherwise with the same technical solution was simulated with national input data. The technical solutions were selected so that the building complied with the requirements in one country. Primary energy values simulated with national input data were then compared with national requirements in other countries, and if a gap existed, the technical solutions were changed to minimize the gap. The requirement of the country corresponding to the technical solutions with highest performance level express the strictest NZEB level. Generally, in the Central and North Europe comparison, national input data caused much more differences than the climate. When comparing national NZEB requirements with European Commission recommendations, a direct comparison did not work, but the building complying with national NZEB requirement was needed to simulate with prEN 16798-1 energy calculation input data and ISO 52000-1:2017 primary energy factors which remarkably changed the results. The following conclusions can be drawn:

- Normalization factors based on solar-air temperature degree days achieved 5\% accuracy in space heating need normalization, but had a limitation of the same insulation thickness in both climates under comparison. To overcome this limitation, an economic insulation thickness concept was introduced. This method requires energy simulation for comparison, whereas degree days based factors calculated from climate files can be directly applied.

- Dry-bulb air temperature based cooling degree days were trustworthy to estimate the cooling need, and it was also noticed that cooling needs were reasonably low in all NZEB in the studied Central and North European climates.

- To avoid the use of building-specific data and simulations, i.e., to operate only with climate files and estimated base temperature, a dry-bulb air temperature-based heating degree days provides a reasonable compromise for space heating need normalization as the differences shown in Table 8 remain acceptable for many practical applications.

- The application of economic insulation thickness to the reference office building and simulations with national input data made it possible to contrast the ambition of NZEB requirements. The energy use changes caused by the differences in national input data generally revealed to be more significant than differences caused by climate, making simple comparison of NZEB requirements impossible.

- The Estonian NZEB requirement for office buildings was revealed to be the strictest one, followed by Finnish, Belgium Brussels capital region and French requirements. The Estonian NZEB requirement was also the only one complying with the European Commission recommendations.

Author Contributions: K. A. wrote the paper and conceived, designed, and performed the simulations. M.C. conceived and collected information form national building codes. C.F. provided the French building code details and contributed to the development of the manuscript. J.K. was the principal investigator responsible for the study design.

Acknowledgments: This research was supported by the K.V. Lindholms Stiftelse foundation and by Estonian Centre of Excellence in Zero Energy and Resource Efficient Smart Buildings and Districts, ZEBE, grant 2014-2020.4.01.15-0016 funded by the European Regional Development Fund.

Conflicts of Interest: The authors declare no conflicts of interest. 


\section{Abbreviations}

\begin{tabular}{|c|c|}
\hline$A_{S}$ & Surface area, $\mathrm{m}^{2}$ \\
\hline$a_{n}$ & Annuity factor, dimensionless \\
\hline C & Constant, dimensionless \\
\hline$C_{D D}$ & Cooling degree days, ${ }^{\circ} \mathrm{Cd}$ \\
\hline$C_{D D^{j}}$ & Respective building cooling degree days, ${ }^{\circ} \mathrm{Cd}$ \\
\hline$C_{D D^{r e f}}$ & Reference building cooling degree days, ${ }^{\circ} \mathrm{Cd}$ \\
\hline$D D_{j}$ & $\begin{array}{l}\text { Respective building heating or cooling degree days with dry-bulb air temperature or } \\
\text { solar air temperature,: }{ }^{\circ} \mathrm{Cd}\end{array}$ \\
\hline$D D_{r e f}$ & $\begin{array}{l}\text { Heating or cooling degree days in reference building with dry-bulb air temperature or } \\
\text { solar-air temperature, }{ }^{\circ} \mathrm{Cd}\end{array}$ \\
\hline$D E$ & Delivered energy, $\frac{\mathrm{kWh}}{\mathrm{m}^{2} \cdot \mathrm{a}}$ \\
\hline DHW & Domestic hot water use, $\frac{1}{\mathrm{~m}^{2} \cdot \mathrm{a}}$ \\
\hline E & Energy need, $\frac{\mathrm{kWh}}{\mathrm{m}^{2} \cdot \mathrm{a}}$ \\
\hline$E_{j}$ & Energy (heating or cooling) need in respective building, $\frac{\mathrm{kWh}}{\mathrm{m}^{2} \cdot \mathrm{a}}$ \\
\hline$E_{j, \mathrm{Norm}}$ & Normalized energy (heating or cooling) need in respective office building, $\frac{\mathrm{kWh}}{\mathrm{m}^{2} \cdot \mathrm{a}}$ \\
\hline$H_{D D}$ & Heating degree days, ${ }^{\circ} \mathrm{Cd}$ \\
\hline$H_{D D^{j}}$ & Respective building heating degree days, ${ }^{\circ} \mathrm{Cd}$ \\
\hline$H_{D D^{r e f}}$ & Reference building heating degree days, ${ }^{\circ} \mathrm{Cd}$ \\
\hline$H N_{R e f, E U}$ & Space heating need for reference building of EU case, $\frac{\mathrm{KWh}}{\mathrm{m}^{2} \cdot \mathrm{a}}$ \\
\hline$H N_{j, E U}$ & Space heating need for respective building of EU case, $\frac{\mathrm{KWh}}{\mathrm{m}^{2} \cdot a}$ \\
\hline HN ratio & Space heating need ratio, dimensionless \\
\hline$h_{0}$ & Heat transfer coefficient for radiation (long wave) and convection, $\frac{\mathrm{W}}{\mathrm{m}^{2} \cdot \mathrm{K}}$ \\
\hline$h_{L}$ & Heating energy unit cost, $\frac{€}{\mathrm{KWh}}$ \\
\hline$K_{H}$ & Maintenance cost, $\frac{€}{\mathrm{~m}^{2} \cdot \mathrm{a}}$ \\
\hline$K v$ & Annual cost of the wall, $\frac{€}{\mathrm{~m}^{2} \cdot \mathrm{a}}$ \\
\hline$K_{R}$ & Unit construction (investment) cost for building, $\frac{€}{\mathrm{~m}^{3}}$ \\
\hline$K_{T}$ & Unit real estate value, $\frac{€}{\mathrm{~m}^{3}}$ \\
\hline$M_{c, \text { alt }}$ & Altitude coefficient, dimensionless \\
\hline$M_{c, g e o}$ & Geographical location coefficient, dimensionless \\
\hline$M_{c, g e s}$ & Greenhouse potential of the fuel used coefficient, dimensionless \\
\hline$M_{\mathcal{c}, \text { surf }}$ & Commercial buildings floor surface coefficient, dimensionless \\
\hline$M_{c, \text { type }}$ & Depending on building type and category coefficient, dimensionless \\
\hline$P E$ & Primary energy use according to national requirement, $\frac{\mathrm{KWh}}{\mathrm{m}^{2} \cdot \mathrm{a}}$ \\
\hline$Q_{\text {conv }+ \text { rad }}$ & Convective and radiative heat flow into the exterior surface, $\mathrm{W}$ \\
\hline$Q_{D H W}$ & Delivered energy use for DHW, $\frac{\mathrm{KWh}}{\mathrm{m}^{2} \cdot \mathrm{a}}$ \\
\hline$Q_{\text {radiation correction }}$ & Correction for the radiation heat transfer when $\mathrm{T}_{\text {surr }} \neq \mathrm{T}_{\mathrm{O}}, \mathrm{W}$ \\
\hline$Q_{\text {Solar }}$ & Solar heat flow, W \\
\hline$Q_{\text {Surface }}$ & Heat flow into the exterior surface, $\mathrm{W}$ \\
\hline$q_{\text {solar }}$ & Solar irradiance, $\frac{\mathrm{W}}{\mathrm{m}^{2}}$ \\
\hline$s$ & Insulation material thickness, $\mathrm{m}$ \\
\hline$T_{0}$ & Dry-bulb temperature, ${ }^{\circ} \mathrm{C}$ \\
\hline$T_{s}$ & Surface temperature, ${ }^{\circ} \mathrm{C}$ \\
\hline$T_{\text {sol-air }}$ & Solar-air temperature, ${ }^{\circ} \mathrm{C}$ \\
\hline$T_{\text {surr }}$ & Surrounding temperature, ${ }^{\circ} \mathrm{C}$ \\
\hline $\mathrm{U}$ & Thermal transmittance, $\frac{\mathrm{W}}{\mathrm{m}^{2} \cdot \mathrm{K}}$ \\
\hline$U_{o p t}$ & Optimal thermal transmittance, $\frac{\mathrm{W}}{\mathrm{m}^{2} \cdot \mathrm{K}}$ \\
\hline$U_{o p t}^{j}$ & Optimal thermal transmittance of respective building, $\frac{\mathrm{W}}{\mathrm{m}^{2} \cdot \mathrm{K}}$ \\
\hline$U_{o p t}^{r e f}$ & Optimal thermal transmittance of reference building, $\frac{\mathrm{W}}{\mathrm{m}^{2} \cdot \mathrm{K}}$ \\
\hline$\lambda$ & Conductivity of the material, $\frac{\mathrm{W}}{\mathrm{m} \cdot \mathrm{K}}$ \\
\hline$\alpha_{S}$ & Solar radiation absorptivity, dimensionless \\
\hline$\varepsilon$ & Surface emissivity, dimensionless \\
\hline$\sigma$ & Stefan-Boltzmann constant, $\frac{\mathrm{W}}{\mathrm{m}^{2} \cdot \mathrm{K}^{4}}$ \\
\hline
\end{tabular}




\section{References}

1. Synnefa, A.; Santamouris, M.; Akbari, H. Estimating the effect of using cool coatings on energy loads and thermal comfort in residential buildings in various climatic conditions. Energy Build. 2007, 39, 1167-1174. [CrossRef]

2. Tsirigoti, D.; Tsikaloudaki, K. The effect of climate conditions on the relation between energy efficiency and urban form. Energies 2018, 11, 582. [CrossRef]

3. Wan, K.K.W.; Li, D.H.W.; Liu, D.; Lam, J.C. Future trends of building heating and cooling loads and energy consumption in different climates. Build. Environ. 2011, 46, 223-234. [CrossRef]

4. Sailor, D.J.; Pavlova, A.A. Air conditioning market saturation and long-term response of residential cooling energy demand to climate change. Energy 2003, 28, 941-951. [CrossRef]

5. Lam, J.C.; Tang, H.L.; Li, D.H.W. Seasonal variations in residential and commercial sector electricity consumption in Hong Kong. Energy 2008, 33, 513-523. [CrossRef]

6. Giannakopoulos, C.; Hadjinicolaou, P.; Zerefos, C.; Demosthenous, G. Changing energy requirements in the Mediterranean under changing cimatic conditions. Energies 2009, 2, 805-815. [CrossRef]

7. Karlsson, J.; Roos, A.; Karlsson, B. Building and climate influence on the balance temperature of buildings. Build. Environ. 2003, 38, 75-81. [CrossRef]

8. Calise, F.; D'Accadia, D.M.; Barletta, C.; Battaglia, V.; Pfeifer, A.; Duic, N. Detailed modelling of the deep decarbonisation scenarios with demand response technologies in the heating and cooling sector: a case study for Italy. Energies 2017, 10, 1535. [CrossRef]

9. Yilmaz, Z. Evaluation of energy efficient design strategies for different climatic zones: Comparison of thermal performance of buildings in temperate-humid and hot-dry climate. Energy Build. 2007, 39, 306-316. [CrossRef]

10. Hekkenberg, M.; Moll, H.C.; Uiterkamp, A.J.M.S. Dynamic temperature dependence patterns in future energy demand models in the context of climate change. Energy 2009, 34, 1797-1806. [CrossRef]

11. Abu Bakar, N.N.; Hassan, M.Y.; Abdullah, H.; Rahman, H.A.; Abdullah, M.P.; Hussin, F.; Bandi, M. Energy efficiency index as an indicator for measuring building energy performance: a review. Renew. Sustain. Energy Rev. 2015, 44, 1-11. [CrossRef]

12. González, A.B.R.; Díaz, J.J.V.; Caamaño, A.J.; Wilby, M.R. Towards a universal energy efficiency index for buildings. Energy Build. 2011, 43, 980-987. [CrossRef]

13. Commission Delegated Regulation (EU) No 244/2012, Supplementing Directive 2010/31/EU of The European Parliament and of The Council on the Energy Performance of Buildings by Establishing a Comparative Methodology Framework for Calculating Cost-Optimal Levels of Minimum Energy performance Requirements for Buildings and Building Elements. 2012. Available online: http:/ / data.europa.eu/eli/reg_del/2012/244/oj (accessed on 1 June 2017).

14. Mahlia, T.M.I.; Iqbal, A. Cost benefits analysis and emission reductions of optimum thickness and air gaps for selected insulation materials for building walls in Maldives. Energy 2010, 35, 2242-2250. [CrossRef]

15. Sisman, N.; Kahya, E.; Aras, N.; Aras, H. Determination of optimum insulation thicknesses of the external walls and roof (ceiling) for Turkey's different degree-day regions. Energy Policy 2007, 35, 5151-5155. [CrossRef]

16. Bolattürk, A. Determination of optimum insulation thickness for building walls with respect to various fuels and climate zones in Turkey. Appl. Therm. Eng. 2006, 26, 1301-1309. [CrossRef]

17. Yang, L.; Lam, J.C.; Tsang, C.L. Energy performance of building envelopes in different climate zones in China. Appl. Energy 2008, 85, 800-817. [CrossRef]

18. Touloupaki, E.; Theodosiou, T. Optimization of external envelope insulation thickness: a parametric study. Energies 2017, 10, 270. [CrossRef]

19. Agostino, D.; Parker, S.D. Comprehensive modeling of optimal paths to reach nearly zero energy buildings (nZEBs) for new constructions in Europe. In Proceedings of the World Sustainable Energy Days Conference, Wels, Austria, 24 February 2016.

20. Pikas, E.; Thalfeldt, M.; Kurnitski, J.; Liias, R. Extra cost analyses of two apartment buildings for achieving nearly zero and low energy buildings. Energy 2015, 84, 623-633. [CrossRef]

21. EU. Directive 2010/31/EU. European Parliament and of the Council of 19 May 2010 on the energy performance of buildings (recast). Off. J. Eur. Union 2013, 13-35. 
22. Casals, X.G. Analysis of building energy regulation and certification in Europe: Their role, limitations and differences. Energy Build. 2006, 38, 381-392. [CrossRef]

23. ISO 52000-1:2017 Energy Performance of Buildings-Overarching EPB Assessment-Part 1: General Framework and Procedures. 2017. Available online: https:/ /www.sis.se/api/document/preview/921995/ (accessed on 4 June 2017).

24. Asdrubali, F.; Bonaut, M.; Battisti, M.; Venegas, M. Comparative study of energy regulations for buildings in Italy and Spain. Energy Build. 2008, 40, 1805-1815. [CrossRef]

25. Kurnitski, J.; Grönlund, V.; Reinikainen, E. Comparison of energy performance requirements in selected countries, CLIMA 2013. In Proceedings of the 11th REHVA World Congress and the 8th International Conference on Indoor Air Quality, Ventilation and Energy Conservation in Buildings, Prague, Czech Republic, 16-19 June 2013.

26. Science for Policy Report: Synthesis Report on the National Plans for Nearly Zero Energy Buildings (nZEBs). 2016. Available online: http:/ / publications.jrc.ec.europa.eu/repository/handle/JRC97408 (accessed on 1 June 2017).

27. Commission Recommendation (EU) 2016/1318 of 29 July 2016 on Guidelines for the Promotion of Nearly Zero-Energy Buildings and Best Practices to Ensure that, by 2020, All New Buildings Are Nearly Zero-Energy Buildings. 2016. Available online: http://data.europa.eu/eli/reco/2016/1318/oj (accessed on 3 June 2017).

28. Ivanov, J. Metalli TN 3 Büroohoone, Lisainvesteeringu ja Energiatõhususe Analü̈̈s; Tallinn University of Technology: Tallinn, Estonia, 2016.

29. Ymparistoministerion Asetus Uuden Rakennuksen Energiatehokkuudesta. 2017. Available online: https://www. finlex.fi/fi/laki/alkup/2017/20171010 (accessed on 18 November 2018).

30. Estonian Government. Methodology for Calculating the Energy Performance of Buildings. 2012. Available online: https:/ / www.riigiteataja.ee/en/eli/520102014002/consolide (accessed on 8 June 2018).

31. Estonian Government. Minimum Requirements for Energy Performance. 2014. Available online: https://www. riigiteataja.ee/en/eli/520102014001/consolide (accessed on 8 June 2018).

32. Centre Scientifique et Technique du Batiment (CSTB). Methode de Calcul Th-BCE 2012; Centre Scientifique et Technique du Batiment: Saint-Martin-d'Hères, France, 2012; Available online: http:/ / www.bulletin-officiel. developpement-durable.gouv.fr/fiches/BO201114/met_20110014_0100_0007\%20annexe.pdf (accessed on 21 June 2018).

33. Buildings Performance Institute Europe (BPIE). Nearly Zero Energy Buildings in Europe; Technical Report; Buildings Performance Institute Europe (BPIE): Brussels, Belgium, 2015.

34. Institut Bruxellois pour la gestion de l'environnement (IBGE). LES EXIGENCES PEB a Partir de 2015; Bruxelles Environnement: Brussels, Belgium, 2016; Available online: http:/ / www.tivoligreencity.be/wpcontent/uploads/PEB_passif_2015_FR.pdf (accessed on 23 May 2018).

35. Kreider, F.J.; Curtiss, S.P.; Rabl, A. Heating and Cooling of Buildings: Design for Efficiency, 2nd ed.; CRC Press: Boca Raton, FL, USA, 2009.

36. Seppänen, O. Rakennusten Lämmitys, 2nd ed.; Suomen LVI-liitto SULVI: Helsinki, Finland, 2001.

37. Gouvernement Bruxellois. Annexe IX: Methode PER Our Les Unites PEB Habitations Individuelles. 2015. Available online: https:/ /leefmilieu.brussels/sites/default/files/user_files/agbr_210213_annexeix_fr.pdf (accessed on 5 June 2017).

38. Gouvernement Bruxellois. Annexe X: Methode PEN Pour Les Unites PEB Bureaux et Services et Enseignement. Statewide Agricultural Land Use Baseline 2015. 2015. Available online: https: / leefmilieu.brussels/sites/default/ files/user_files/agbr_210313_annexex_fr.pdf (accessed on 5 June 2017).

39. Carlier, M. Nearly Zero Energy Building Definations in Selected Countries; Ghent University: Ghent, Belgium, 2016.

40. IDA Indoor Climate and Energy, Equa Simulations AB. 2015. Available online: https://www.equa.se/en/ ida-ice (accessed on 1 December 2017).

41. Energy Efficiency of Buildings—Regulations and Guidelines. D3 National Building Code of Finland, Ministry of the Environment, Department of Built Environment. 2012. Available online: https:/ / www.google.com.sg/url? $\mathrm{sa}=\mathrm{t} \& \mathrm{rct}=\mathrm{j} \& \mathrm{q}=\& \mathrm{esrc}=\mathrm{s} \&$ source $=$ web\&cd $=1 \& \mathrm{ved}=0$ ahUKEwiC1rGA3ZrbAhXEGZQKHUJ3DngQFggnMAA\& url=http $\% 3 \mathrm{~A} \% 2 \mathrm{~F} \% 2 \mathrm{Fec}$.europa.eu $\% 2$ Fgrowth $\% 2$ Ftools-databases $\% 2$ Ftris $\% 2$ Fen $\% 2$ Findex.cfm $\%$ 2Fsearch\%2F\%3Ftrisaction\%3Dsearch.detail\%26year\%3D2010\%26num\%3D640\%26dLang\%3DEN\&usg= AOvVaw3TvGYgvllK_SQtleRxYkU_ (accessed on 23 May 2018). 
42. De Vlaamse Regering. Bijlage VI: Bepalingsmethode Van Het Peil Van Primair Energieverbruik Van Kantoor-en Schoolgebouwen. 2015. Available online: http://www2.vlaanderen.be/economie/ energiesparen/epb/doc/BijlageEPU20131129vergunningenVOOR2014aangiftesNA2014.pdf (accessed on 15 June 2017).

43. FprEN 16798-1:2017 Energy Performance of Buildings-Part 1: Indoor Environmental Input Parameters for Design and Assessment of Energy Performance of Buildings Addressing Indoor Air Quality, Thermal Environment, Lighting and Acoustics-Module M1-6. 2017. Available online: https:/ / www.rehva.eu/publications-and-resources/rehva-journal/2015/012015/indoor-environmentalinput-parameters-for-the-design-and-assessment-of-energy-performance-of-buildings.html (accessed on 20 December 2017).

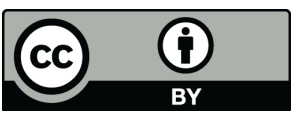

(C) 2018 by the authors. Licensee MDPI, Basel, Switzerland. This article is an open access article distributed under the terms and conditions of the Creative Commons Attribution (CC BY) license (http://creativecommons.org/licenses/by/4.0/). 